\title{
Genetic Association and Role of Surgery for the Treatment of Lower Limb Deformities in Diastrophic Dysplasia: A Case Report
}

\author{
Anchal Kumar Tripathi ${ }^{1}$, Sunny Choudhary ${ }^{2}$, Vivek Singh ${ }^{2}$, Prashant Kumar Verma ${ }^{1}$ \\ Learning Point of the Article: \\ Early genetic diagnosis and orthopedic care improves the outcome of diastropic dysplasia.
}

\section{Abstract}

Introduction: Diastrophic dysplasia (DTD) results from SCN26A2 gene mutation, with autosomal recessive inheritance and widely variable phenotype. The gene has been mapped to chromosome 5q32-q33.1.

Case Report: We present a case of a 4-year-old female with short stature, bilateral feet and knee deformity, and dysplastic facies. SCN26A2 mutations were seen in patient as well as parents. She underwent multiple orthopedic procedures involving metatarsals, gastrosoleus, and distal femur. Based on typical clinical features, DTD was suspected. Genetic studies of patient and parents provided the exact diagnosis in this case.

Conclusion: Genetic diagnosis and family counseling are important caveat of management. Key features like ear abnormalities help to suspect diagnosis which requires a high index of suspicion. Associated bony and soft-tissue abnormalities of lower limb may require surgical intervention for improvement of gait, functions, and cosmesis.

Keywords: Diastrophic dysplasia, Skeletal dysplasia, Ear abnormalities, SCN26A2, Osteotomy.

\section{Introduction}

Bones and cartilage are the predominantly affected structures in skeletal dysplasias, various other manifestations are seen as a consequence of these dysplasias [1]. Mutations in genes encoding diastrophic dysplasia (DTD) sulfate transporter (DTDST or SLC26A2) lead to the development of a group of skeletal dysplasias that comprise the most severe phenotypic disorder called achondrogenesis $1 \mathrm{~B}$ followed by atelosteogenesis 2 and less severe phenotypic presentations in DTD and recessive multiple epiphyseal dysplasia with possible genotype and phenotype relationship. All these disorders are autosomal recessive in inheritance patterns. The gene has been mapped to chromosome 5q32-q33.1. The protein encoded by this SLC6A2 gene acts as sulfate/chloride antiporter of the cartilage cell membrane. In turn, cartilage cells incorporate sulfate ions to manufacture proteoglycans [2].

\section{Case Report}

A 4-year-old female presented to genetic OPD for evaluation of short stature. Her weight $=16.2 \mathrm{Kg}$ (median to -2 standard deviation $[\mathrm{SD}])$, height $=92 \mathrm{~cm}(<-3 S \mathrm{SD})$. On examination, the patient had thickened auricular cartilage (Fig. 1) with preauricular pits, blue sclerae, dental caries with enamel dysplasia (Fig. 2), syndactyly, brachydactyly, and joint laxity. The patient had unassisted bipedal gait with bilateral intoeing and equinus at the right ankle. There was bilateral genu valgum deformity with patellar subluxation. The clinical tibiofemoral angle was $13^{\circ}$ on the right side and $15^{\circ}$ on the left side. The Apprehension test for a patellar subluxation was negative. There was an extension lag of $10^{\circ}$ on both knees and equinus deformity of $20^{\circ}$ at the right ankle. Bilateral metatarsus adductus was present. Radiographs of the pelvis with both hips revealed bilateral

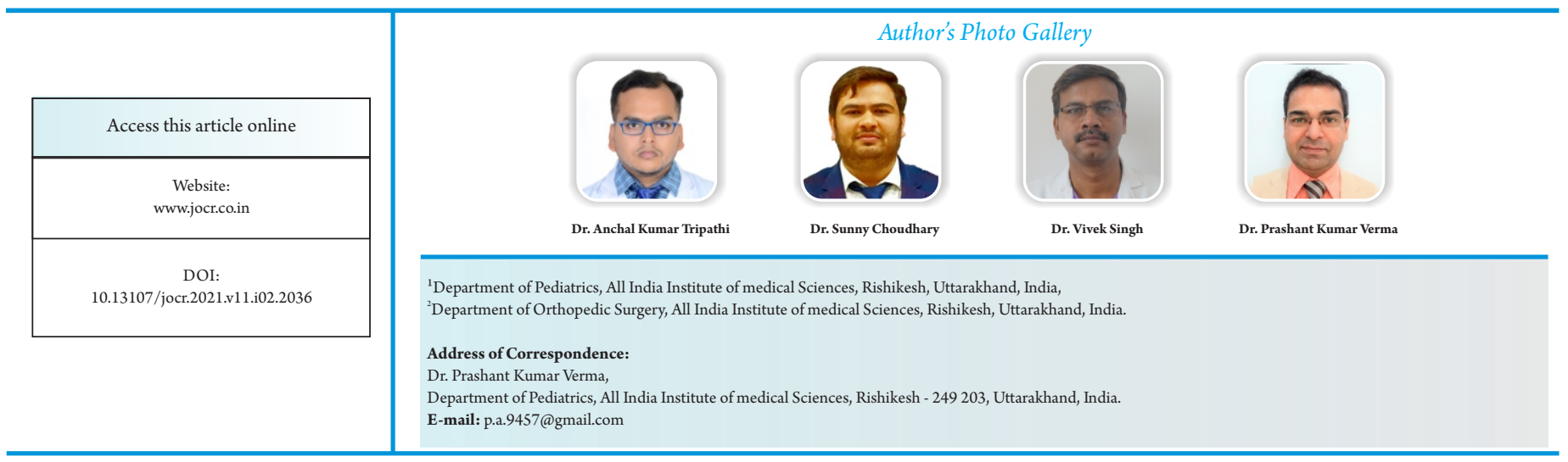

Journal of Orthopaedic Case Reports | pISSN 2250-0685 | eISSN 2321-3817 | Available on www.jocr.co.in | doi:10.13107/jocr.2021.v11.i02.2036 This is an Open Access article distributed under the terms of the Creative Commons Attribution Non-Commercial License (http://creativecommons.org/licenses/by-nc/3.0) which permits unrestricted non-commercial use, distribution, and reproduction in any medium, provided the original work is properly cited. 


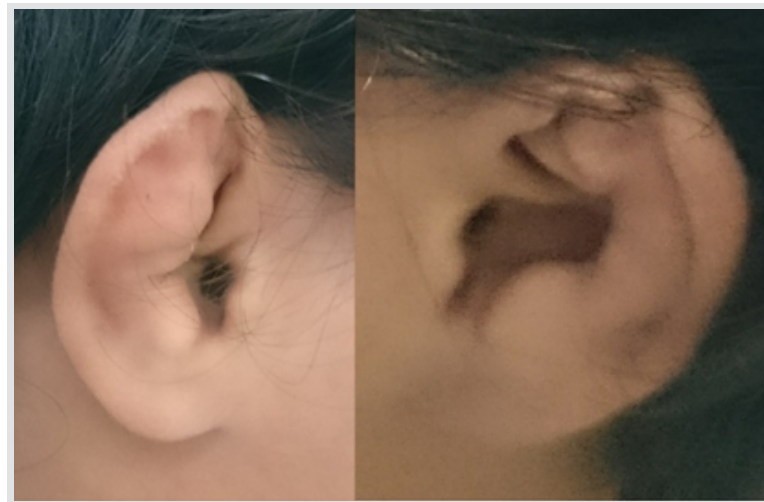

Figure 1: Ear cartilage abnormalities in the patient.

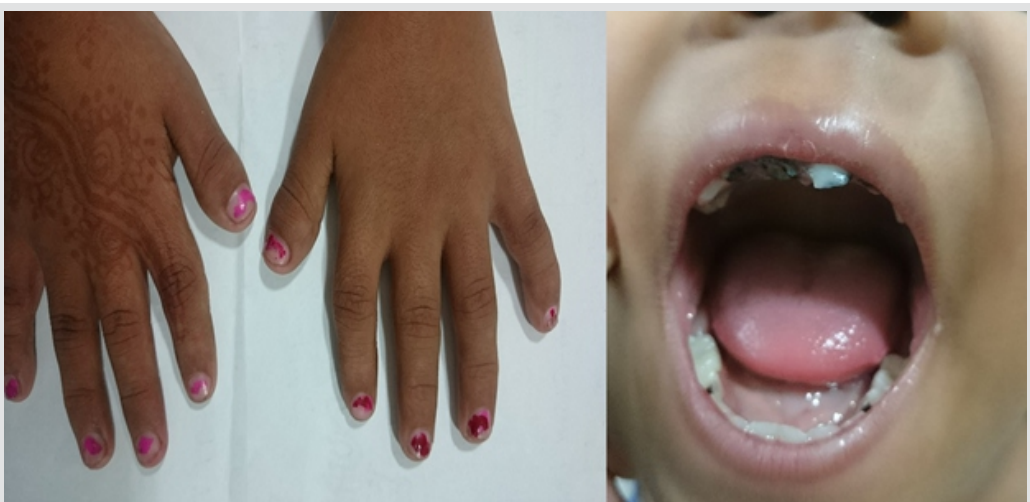

Figure 2: Brachydactyly and enamel dysplasia in the patient. rudimentary femoral epiphysis with fragmentation (Fig. 3).

Based on these features, the diagnosis of skeletal dysplasia was suspected, and genotyping was offered to the family after counseling.

Serial casts for foot deformity were applied but there was no improvement. Metatarsus adductus on each side was corrected by multiple dome osteotomies of metatarsals (Figs. 4a and b). Surgical correction of bilateral genu valgum by medial distal femoral hemiepiphysiodesis was done (Figs. 5a and b). The right side equinus deformity was treated by the Vulpius V-Y plasty of gastrosoleus aponeurosis. On the latest follow-up at 1 $1 / 2$ years post-surgery, residual genu valgum deformity was noted on the left side and so osteotomy at appropriate age was planned. Clinical correction of metatarsus adductus was achieved with a plantigrade foot (Fig. 6).

\section{Molecular data}

Getting the preliminary data and report by NGS, Exon 3 of the SLC26A2 gene was PCR amplified and the product was sequenced using Sanger sequencing. In case of mosaicism in leukocytes, the detection limits of Sanger sequencing for the presence of variation are $\sim 12 \%$. The sequence was aligned to available reference sequence ENST00000286298 to detect variation using variant analysis software programs. Figs 7, 8, and 9 show variation in the SLC26A2 gene in patient, her father, and mother, respectively.

\section{Discussion}

Clinical features of this case bilateral symmetrical cystic ear swelling (hypertrophic ear cartilage), equinus deformity in feet, brachydactyly with ulnar deviation, and short stature are consistent with DTD (due to SLC26A2 mutation) [3]. Persistence of ear abnormalities is seen only in this form of SLC26A2-related disorders (Table 1). The DTDST protein has a complex structure with 12 membrane-spanning domains. Multiple mutations have been noted which result in a myriad combination of clinical features, either through protein truncation or through the reduction in mRNA levels [4]. Mutations leading to amino acid substitutions in the transmembrane portion of protein have severe phenotypical expression than substitutions involving extracellular or cytoplasmic part (N-terminal and $\mathrm{C}$-terminal). It is postulated that there is a leftover activity associated with some mutations and the degree of this leftover activity determines the clinical phenotype [4]. Both skeletal dysplasia and achondroplasia have similar features but morbidity is significantly higher with DTD.

Yilmaz et al. in their study consisting of 29 patients of skeletal dysplasia with genu valgum deformity in 38 legs showed hemiepiphysiodesis to be effective in the treatment of genu valgum deformities in skeletally immature patients [5].

Cavovarus deformity which is often present is treated with the Ponseti method of casting in patients in the age group $<6$ months. There is a need for soft-tissue release in patients with after the walking age and in resistant cases, it may need aggressive release [6]. Metatarsus adductus deformity if

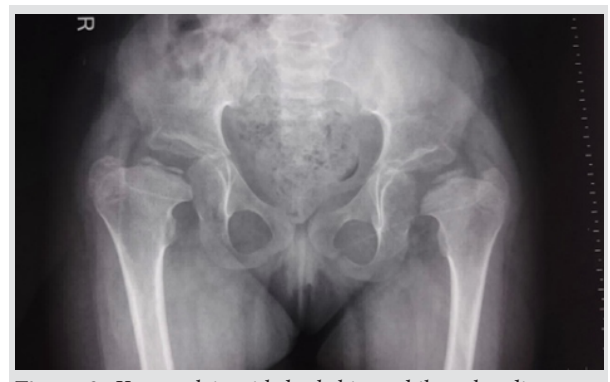

Figure 3: X-ray pelvis with both hips - bilateral rudimentary femoral epiphysis with fragmentation.

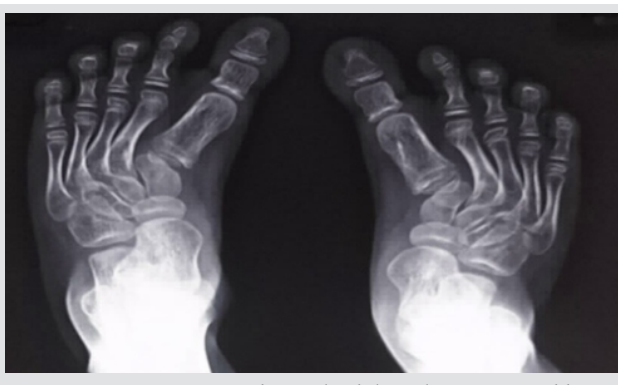

Figure 4a: Pre-operative radiograph - bilateral metatarsus adductus deformity.

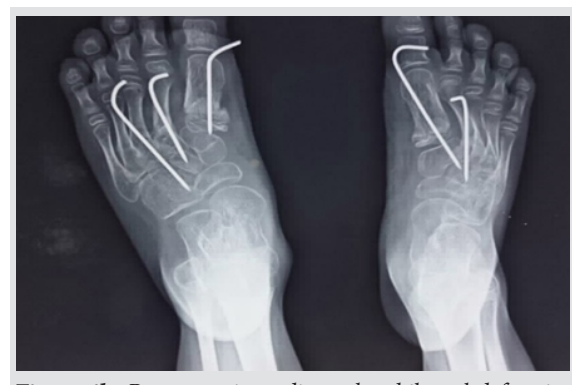

Figure 4b: Post-operative radiograph - bilateral deformity correction by multiple metatarsal osteotomies. 


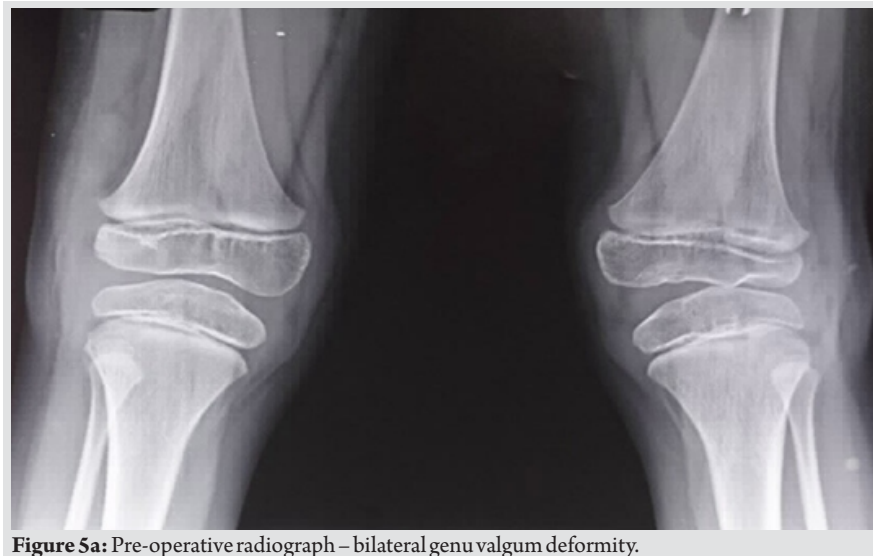

Figure 5a: Pre-operative radiograph - bilateral genu valgum deformity.

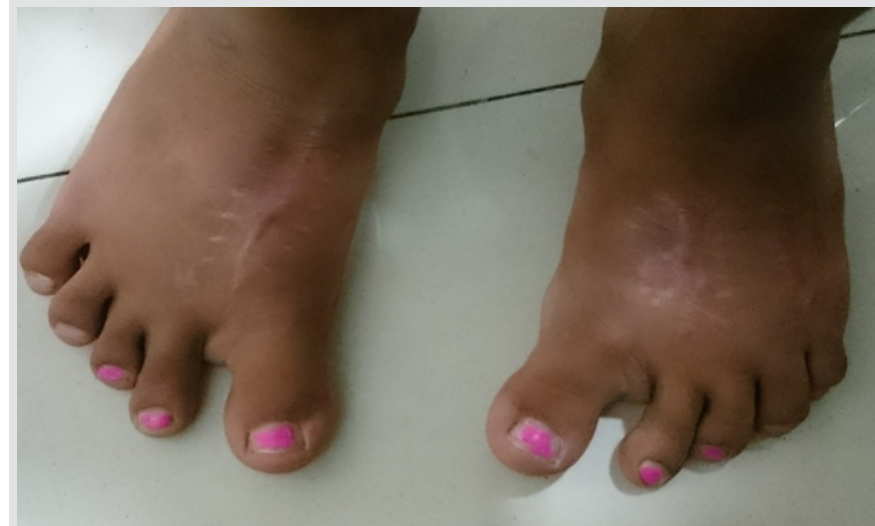

Figure 6: Post-operative clinical image of foot - healed surgical scar mark with the improvement of deformity.

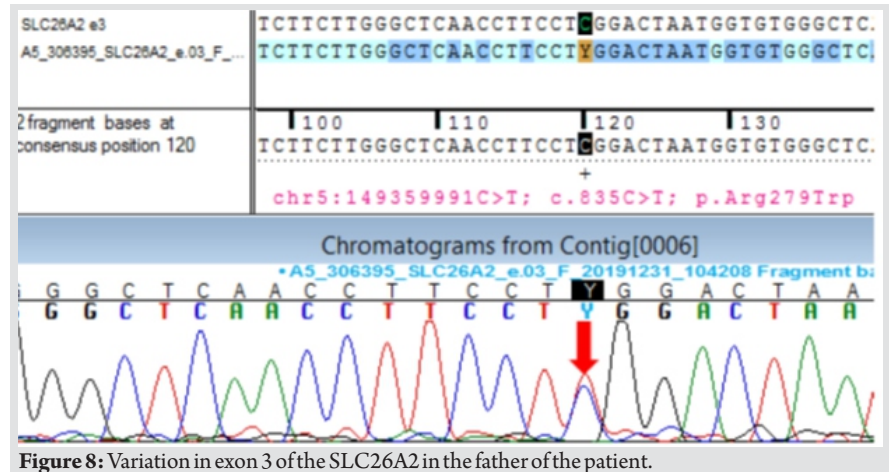

resistant may need bony procedures and various ostetomies have been described $[7,8,9]$. A multidisciplinary approach is indicated with the treating team comprising a pediatrician, orthopedic surgeon, audiologist, orthodontists, and physical therapists. Genetic studies have a crucial role in diagnosis, but importance of clinical suspicion (based on certain characteristic deformities) cannot be emphasized more.

\section{Conclusion}

Skeletal dysplasias are heterogeneous disorders with widely varying clinical presentations - from mildly symptomatic to overtly fatal. Diagnosis of such cases is tricky in our setup due to lack of investigative set up as well as high costs. However, efforts

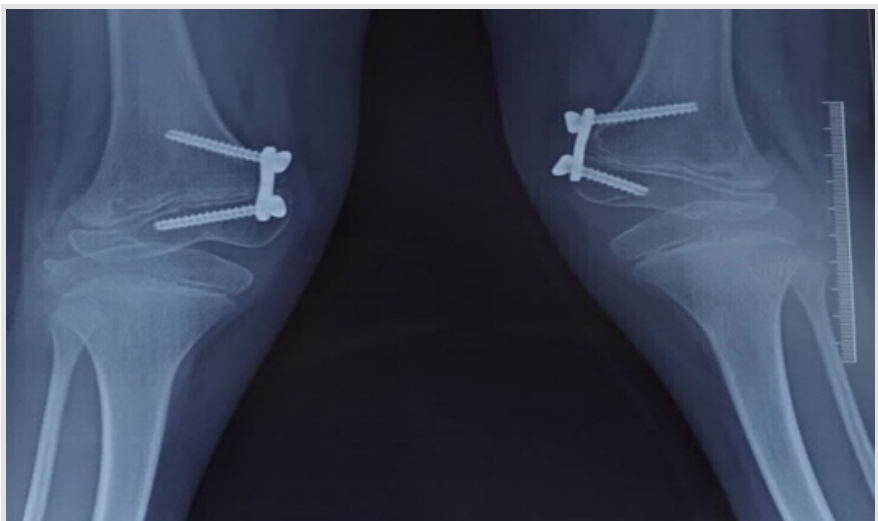

Figure 5b: Post-operative radiograph - bilateral medial hemiepiphysiodesis done using eight plates

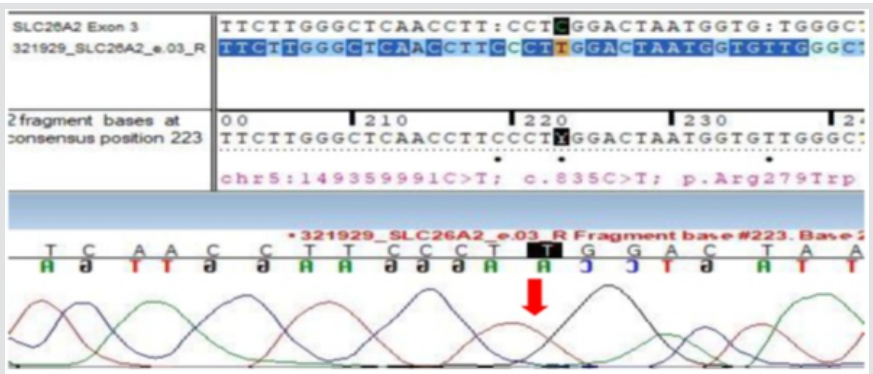

Figure 7: Sequence chromatogram and alignment to the reference sequence showing the variation in exon 3 of the SLC26A2

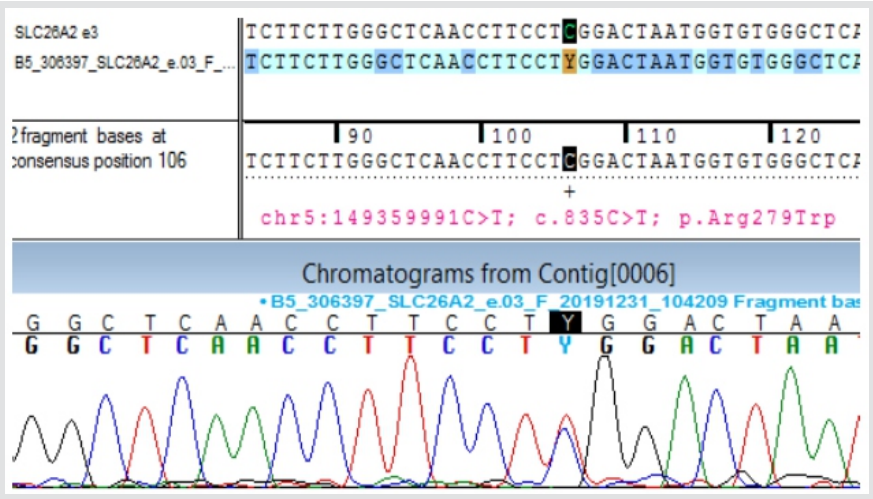

Figure 9: Variation in exon 3 of SLC26A2 in mother of the patient.

into a search for diagnosis and dedicated management by a team of skilled clinicians have potential to improve quality of life for patients afflicted by such disorders.

\section{Clinical Message}

A multidisciplinary approach is warranted for providing best possible management to such patients. Selected certain anomalies serve as a key feature to identify a disorder (ear abnormalities in this case) and clinicians should be mindful of these. Family counseling regarding prognosis and genetic implication forms the crux of care and helps in improving outcomes, long-term care, and further family planning. 


\begin{tabular}{|c|c|c|c|c|}
\hline Tripathi AKet al & & & & www.jocr.co.in \\
\hline \multicolumn{5}{|l|}{ Table 1: Clinical features } \\
\hline & $\begin{array}{l}\text { Achondrogenesis, type IB; } \\
\text { ACG1B (OMIM NO. 600972) }\end{array}$ & $\begin{array}{l}\text { Atelosteogenesis, type II; AO2 } \\
\text { (OMIM NO. 256050) }\end{array}$ & $\begin{array}{l}\text { Diastrophic dysplasia; DTD } \\
\text { (OMIM NO. 222600) }\end{array}$ & $\begin{array}{c}\text { Epiphyseal dysplasia, multiple, 4; EDM4 } \\
\text { (OMIM NO. 226900) }\end{array}$ \\
\hline Growth & $\begin{array}{l}\text { Height - Short-limbed dwarfism } \\
\text { identifiable at birth }\end{array}$ & $\begin{array}{l}\text { Height - Short-limbed dwarfism } \\
\text { identifiable at birth }\end{array}$ & $\begin{array}{c}\text { Height - Mean birth length } 42 \mathrm{~cm} \text {, } \\
\text { specific growth curve available - Adult } \\
\text { height } 100-140 \mathrm{~cm} \text {, short-limb } \\
\text { dwarfism }\end{array}$ & Height - Short stature $\left(3^{\text {rd }}-90^{\text {th }}\right.$ centile $)$ \\
\hline \multirow[t]{3}{*}{ Head, face, and neck } & Head - Flat face & $\begin{array}{c}\text { Face - Midface hypoplasia, } \\
\text { micrognathia, flattened nasal bridge, } \\
\text { cleft palate }\end{array}$ & Head - Normocephaly & $\begin{array}{l}\text { Cystic lesions of the pinnae at birth usually } \\
\text { disappear with age }\end{array}$ \\
\hline & & Neck - Short neck & $\begin{array}{l}\text { Ears - Neonatal cystic lesions of the } \\
\text { pinnae, hypertrophic auricular } \\
\text { cartilage, ossified pinnae, hearing loss }\end{array}$ & \\
\hline & & & Mouth - Cleft palate & \\
\hline Lungs & Respiratory insufficiency & $\begin{array}{l}\text { Respiratory insufficiency, pulmonary } \\
\text { hypoplasia }\end{array}$ & Laryngotracheal stenosis & \\
\hline \multirow[t]{3}{*}{ Chest } & - Narrow chest & - Small thorax & Costal cartilage calcification & \\
\hline & - Thin short ribs & & & \\
\hline & - Occasional rib fractures & & & \\
\hline \multirow[t]{2}{*}{ Abdomen } & - Umbilical and inguinal hernia & & & \\
\hline & - Distended abdomen & & & \\
\hline \multirow[t]{14}{*}{ Skull \& spine } & Skull & Spine & Spine & Spine - Scoliosis \\
\hline & - Delayed ossification & $\begin{array}{l}\text { - Cervical kyphosis, platyspondyly, } \\
\text { vertebral body coronal clefts, } \\
\text { scoliosis, lumbar hyperlordosis, } \\
\text { horizontal sacrum }\end{array}$ & - Kyphoscoliosis & Pelvis - Hip dysplasia, small femoral heads \\
\hline & $\begin{array}{c}\text { Spine - Absent or minimally ossified } \\
\text { vertebral bodies }\end{array}$ & Pelvis & - Hypoplastic cervical vertebrae & - Flattened proximal femoral epiphyses \\
\hline & $\begin{array}{l}\text { Pelvis } \\
\end{array}$ & - Round-shaped iliac bones & - Cervical kyphosis & Limbs \\
\hline & - Small iliac bones & - Flat acetabulae & Pelvis - Hip contractures & $\begin{array}{l}\text { - Limited elbow flexion, double-layered } \\
\text { patella, arthralgia, small humeral, distal radii, } \\
\text { and ulnae epiphyses, mildly shortened ulna, } \\
\text { flat proximal femoral epiphyses }\end{array}$ \\
\hline & - Unossified ischium and pubis & - Shortened sacroiliac notches & Limbs & Hands \\
\hline & Limbs & Limbs & $\begin{array}{c}\text { - Short, thick tubular bone, with broad } \\
\text { metaphyses and flattened, irregular } \\
\text { epiphyses }\end{array}$ & - Brachydactyly \\
\hline & - Severe micromelia & - Severe micromelia & - Subluxed patella & - Mild shortened metacarpals \\
\hline & $\begin{array}{l}\text { - Marked shortness, broad tubular } \\
\text { bone }\end{array}$ & - Bifid distal humerus & Hands & Feet \\
\hline & - Metaphyseal spurring & - Short, dumbbell femur & - Short finger with ulnar deviation & - Clubfoot \\
\hline & & - Abducted thumbs and great toes & - Hitchhiker thumb & \\
\hline & & - Gap between first and second toe & Feet & \\
\hline & & $\begin{array}{c}\text { - Hypoplastic, rounded middle } \\
\text { phalanges }\end{array}$ & - Talipes equinovarus & \\
\hline & & - Talipes equinovarus & & \\
\hline Skin & & & Glabellar hemangioma & \\
\hline CNS & & & $\begin{array}{l}\text { Normal intelligence, spinal cord } \\
\text { compression }\end{array}$ & \\
\hline Voice & & & Hoarse voice & \\
\hline \multirow[t]{2}{*}{ Prenatal manifestations } & Polyhydramnios, fetal hydrops & & & \\
\hline & $\begin{array}{c}\text { - Breech presentation at birth, often } \\
\text { stillborn }\end{array}$ & - Stillborn or death shortly after birth & & \\
\hline Laboratory abnormalities & $\begin{array}{c}\text { - No cartilage staining with toluidine } \\
\text { blue, impaired synthesis of fibroblast } \\
\text { sulfated proteoglycans }\end{array}$ & $\begin{array}{l}\text { - Lacunar halos around } \\
\text { chondrocytes in skeletal cartilage }\end{array}$ & & \\
\hline
\end{tabular}

\section{References}

1. Krakow D. Skeletal dysplasias. Clin Perinatol 2015;42:30119.

2. Singh P, Schwarzbauer JE. Fibronectin matrix assembly is essential for cell condensation during chondrogenesis. J Cell Sci 2014;127:4420-8.

3. Bonafé L, Mittaz-Crettol L, Ballhausen D, Superti-Furga A. Diastrophic Dysplasia. Seattle, WA: University of
Washington; 2004.

4. Rossi A, Superti-Furga A. Mutations in the diastrophic dysplasia sulfate transporter (DTDST) gene (SLC26A2): 22 novel mutations, mutation review, associated skeletal phenotypes, and diagnostic relevance. Hum Mutat 2001;17:159-71.

5. Yilmaz G, Oto M, Thabet AM, Rogers KJ, Anticevic D, 
Thacker MM, et al. Correction of lower extremity angular deformities in skeletal dysplasia with hemiepiphysiodesis: A preliminary report.J Pediatr Orthop 2014;34:336-45.

6. Al Kaissi A, Kenis V, Melchenko E, Chehida FB, Ganger R, Klaushofer K, et al. Corrections of lower limb deformities in patients with diastrophic dysplasia. Orthop Surg 2014;6:274-9.

7. Steytler JC, Van der Walt ID. Correction of resistant adduction of the forefoot in congenital club-foot and congenital metatarsus varus by metatarsal osteotomy. $\mathrm{Br} \mathrm{J}$ Surg 1966;53:558-60.

8. Berman A, Gartland JJ. Metatarsal osteotomy for the correction of adduction of the fore part of the foot in children.J Bone Joint Surg Am 1971;53:498-506.

9. Siegel SJ. The modified lepird procedure for correction of metatarsus adductus.J Foot Ankle Surg 2019;58:1045-50.
Conflict of Interest: Nil

Source of Support: Nil

Consent: The authors confirm that informed consent was obtained from the patient for publication of this case report

\section{How to Cite this Article}

Tripathi AK, Choudhary S, Singh V, Verma PK. Genetic Association and Role of Surgery for the Treatment of Lower Limb Deformities in Diastrophic Dysplasia: A Case Report. Journal of Orthopaedic Case Reports 2021 February;11(2): 81-85. 